\title{
Water Environmental Carrying Capacity in Urban Agglomeration of Yogyakarta City
}

\author{
Yogafanny, E. \\ Departement of Environmental Engineering \\ University of Pembangunan Nasional \\ Yogyakarta, Indonesia \\ Corresponding E-mail: ekha.yogafanny@upnyk.ac.id \\ Wardoyo, S.S. \\ Departement of Agrotechnology \\ University of Pembangunan Nasional \\ Yogyakarta, Indonesia \\ Susanto, J. \\ Departement of Economics Science \\ University of Pembangunan Nasional \\ Yogyakarta, Indonesia
}

\begin{abstract}
In the last decade, the urban agglomeration of Yogyakarta City (UAYC) where the area is bounded by the outer ring road of Yogyakarta, has undergone changes in land use significantly especially in the built-land reaching $85.36 \%$ of its total area in 2015. This study was aimed to analyze water environmental carrying capacity in UAYC and to evaluate the method mentioned in The Regulation of Environment Minister Republic Indonesia (REMRI) No.17/2009. This method was used to calculate the amount of $S_{A}$ and $D_{A}$ in the study area by survey (primary and secondary data) and studio analysis. The results showed that the $S_{A}$ was $93,570,587 \mathrm{~m}^{3} / y r$ and the $D_{A}$ was $1,113,329,600 \mathrm{~m}^{3} / \mathrm{yr}$, so that the WECC value was 0.1 . These mean that the value of $D_{A}$ is much larger than $S_{A}\left(S_{A}<D_{A}\right)$, which means that the ability of WECC to fulfill the needs of water for a decent life has been exceeded or deficit for the year 2015. The evaluation of method used by REMRI No.17/2009 was conducted by comparing the calculations and results of REMRI No.17/2009 to those of the mix method commonly used in Indonesia. The mix method resulted the value of WECC 3.1 which means that the water carrying capacity was save. From the evaluation, it can be summed up that the REMRI No.17/2009 was relevant to be used as a long-term approach of the sustainable spatial planning even though there are some parameters need to be discussed in advance. On the other hand, the mix method was also possible to be used as a medium-term approach to make strategy of water management and the result gained by this method was closer to the reality than those by the previous one.
\end{abstract}

Keywords-Water environment carrying capacity, urban agglomeration, Yogyakarta city

\section{INTRODUCTION}

The high of population growth coupled with the increase of economic activity, as well as changes in consumption patterns and technological developments have been giving occasion to the pressure on the environment. Economic activity becomes increasingly complex and it causes the high consumption of natural resources. The increase of population number with all of those activities led to the increase the demand of land resources for social and economic activities (built-land), and as a result the non-build land use would on the wane. Continuously increased of population densities will result in exceeding the environmental carrying capacity and will eventually lead to various problems (Asdak C. and Hilmi S., 2006). Reference (Baiquni M. and Chafid Fandeli, 2012) found that the land in the region has limitations to support a number of residents with activities in order to achieve the desired level of welfare.

Environmental carrying capacity of each region is different. This is because every region has different geographical characteristics and socio-economic activities. If the level of the carrying capacity of the region is still high, it means that the development of economic activities in this region is allowed to be done (Cui X. Q.; Sun W.C.; Yu J. S. et al., 2013). In the reality, most people living in a relatively high environmental carrying capacity tend to pay less attention to the environmental impact of their activities. This phenomenon will cause the deterioration on environmental quality or carrying capacity to support human life. Water environmental carrying capacity is one of an important key parameter to indicate the level of sustained development of a region (Fu G.Z.; Jia L.; Li C., 2013), (Liu C.H.; Shen Y.T.; Zhou M.Y.; et al., 2013), (Mustari K. and Mapangaja B., 2005).

The research area covered three regencies i.e. Yogyakarta City, Part of Sleman Regency, and Part of Bantul Regency, which was deemed as areas of influenced by the urbanization of Yogyakarta City. This area is physically bounded by the outer ring road of Yogyakarta Province with an area of $96.8 \mathrm{~km} 2$. In the last decade, the urban agglomeration of Yogyakarta City (UAYC) has undergone changes in landuse significantly. This landuse change was triggered by the high demand of lands for 
settlements, industries, business units, and education buildings, that in 2015 reaching $\pm 85.36 \%$ of impermeable area in UAYC.

There are various types of activities grown in the region of UAYC such as industry, trade, services (including education and tourism), and settlements. This area has developed into an urban ecosystem dominated by man-made structure. The developments that are being intensively worked out in the study area are hotel, apartments, shops, housing, and mall. Reference [7] found that in Yogyakarta Province, the development of settlement areas was $71 \%$, commercial properties were $26 \%$, and the rest was for industries. As a result, there is a big shift in land use from agriculture to non-agricultural activities. Consequently, the fresh water demand for the industrial and domestic purposes will tend to increase. This condition will not bring a negative impact to the people living in UAYC only if the water environmental carrying capacity (WECC) is in the safe level. According to those reasons, this study aims to analyze water environmental carrying capacity in Urban Agglomeration of Yogyakarta City and to evaluate the method mentioned in The Regulation of Environment Minister Republic Indonesia (REMRI) No.17 Year 2009.

\section{METHOD}

The water availability and water demand were determined based on the method mentioned in the remri no.17/2009. This method was subjected to determine the environmental carrying capacity. Within this method, it is known in general whether the water resources in a region are surplus or deficit. The surplus state shows that the availability of water in a region meets the water demand, while the deficit state indicates that the water availability cannot meet the water demand. The result of calculation by this method can be used as a consideration in preparation of spatial planning and land use evaluation in order to provide sustainable water resources.

The determination of the water carrying capacity is done by comparing the water availability and water demand that can be seen in Fig. 1.

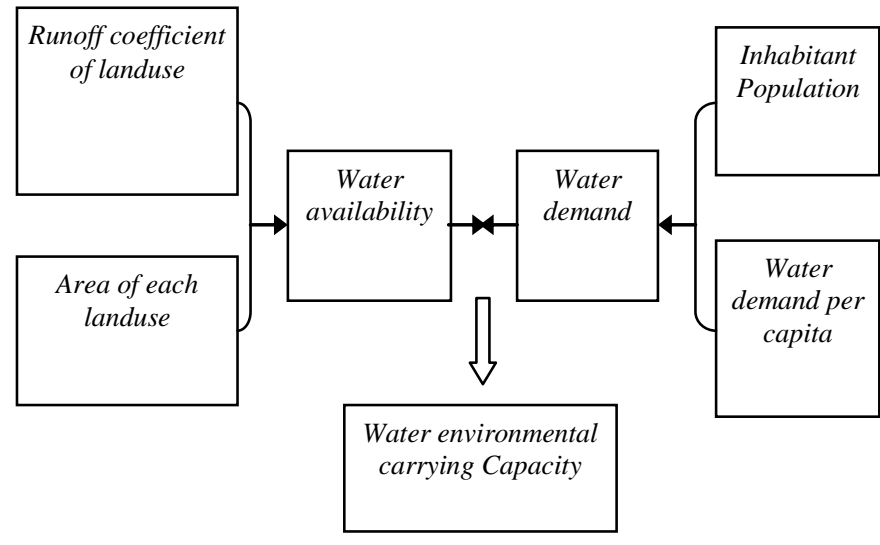

Fig. 1. Diagram of Determination of Water Carrying Capacity

Meanwhile, Calculations are done in stages as follows:

\section{A. Water Availability}

Water availability is determined by using the runoff coefficient through the modified rational method based on the information of land use and the data on annual rainfall. The formulas are explained in Equation (1), (2), and (3).

$$
\begin{aligned}
& C=\Sigma(c i x A i) / \Sigma a i \\
& R=\Sigma R i / m \\
& S_{A}=10 \times C \times R \times A
\end{aligned}
$$

Where $\mathrm{S}_{\mathrm{A}}$ is the water availability $\left(\mathrm{m}^{3} / \mathrm{yr}\right) ; \mathrm{C}$ is the weighted runoff coefficient; ci is runoff coefficient of land use $\mathrm{i}$; $\mathrm{Ai}$ is the area of land use $\mathrm{i}$ (ha); $\mathrm{R}$ is the average annual rainfall algebra area $(\mathrm{mm} / \mathrm{yr})$; $\mathrm{Ri}$ is the annual rainfall at station $\mathrm{i} ; \mathrm{m}$ is the amount of rainfall observation stations; $\mathrm{A}$ is the area (ha); and 10 is the conversion factor from $\mathrm{mm}$ ha into $\mathrm{m}^{3}$. The runoff coefficient for each land use can be seen in Table 1.

TABLE 1. RUNOFF COEFFICIENT OF LANDUSE

\begin{tabular}{|c|l|l|}
\hline No & \multicolumn{1}{|c|}{ Land Cover } & \multicolumn{1}{|c|}{$\mathbf{C i}$} \\
\hline 1 & City, asphalted road, roof tile & $0,7-0,9$ \\
\hline 2 & Industrial area & $0.5-0.9$ \\
\hline 3 & Multi-unit settlement area, shopping & $0.6-0.7$ \\
& centre & \\
\hline 4 & Housing complex & $0.4-0.6$ \\
\hline 5 & Villa & $0.3-0.5$ \\
\hline 6 & Park, cementery & $0.1-0.3$ \\
\hline 7 & Yard of heavy land: & \\
& a. > 7\% & $0.25-0.35$ \\
& b. 2-7\% & $0.18-0.22$ \\
& c. <2\% & $0.13-0.17$ \\
\hline 8 & Yard of lightweight land: & $0.15-0.2$ \\
& a. > 7\% & $0.10-0.15$ \\
& b. 2-7\% & $0.05-0.10$ \\
\hline 9 & c. $\quad$ Heavy land & 0.40 \\
\hline 10 & Meadow & 0.35 \\
\hline 11 & Land for agricultural cultivation & 0.30 \\
\hline 12 & Production forest & 0.18 \\
\hline
\end{tabular}

\section{B. Water Demand}

The water demand is calculated from the results of the conversion of water demand for each person to reach a decent living. The formulas is written in Equation (4).

$$
D_{A}=N \times \text { Khla }
$$

Where $\mathrm{D}_{\mathrm{A}}$ is the water demand $\left(\mathrm{m}^{3} /\right.$ year); $\mathrm{N}$ is the number of population (capita); and Khla is the water demand standard for a decent life (1600 $\mathrm{m}^{3}$ of water/capita/year). The water demand standard is derived from the calculation determined by the REMRI No 17/2009 where it is from $2 \times 800 \mathrm{~m}^{3}$ of water/capita/year. The number of 2 is the correction factor to measure the water demand for a decent life including food, domestic, and other needs of water. The number of $800 \mathrm{~m}^{3}$ of water/capita/year is derived from the standard of water demand for domestic use and to produce food that can be seen in Table 2 . 
TABLE 2. TOTAL OF WATER DEMAND

\begin{tabular}{|c|c|c|}
\hline $\begin{array}{c}\text { Type of } \\
\text { consumption }\end{array}$ & Amount & Equivalent water demand \\
\hline Rice & $120 \mathrm{~kg} /$ year & $324.00 \mathrm{~m}^{3} /$ year \\
\hline $\begin{array}{c}\text { Drinking and } \\
\text { domestic water }\end{array}$ & $1201 /$ day & $43.20 \mathrm{~m}^{3} /$ year \\
\hline Egg & $\begin{array}{c}1 \mathrm{~kg} \text { contains } 16 \text { eggs; } \\
1 \text { egg/day }\end{array}$ & $105.75 \mathrm{~m}^{3} /$ year \\
\hline Fruit & $\begin{array}{c}1 \mathrm{~kg} \text { of orange }=5 \\
\text { oranges; } 1 / 5 \mathrm{~kg} / 3 \text { days }\end{array}$ & $3.84 \mathrm{~m}^{3} /$ year \\
\hline Meat & $1 / 10 \mathrm{~kg} / 5$ days & $20.16 \mathrm{~m}^{3} /$ year \\
\hline Salad & & $5.40 \mathrm{~m}^{3} /$ year \\
\hline Soybean & & $276.00 \mathrm{~m}^{3} /$ year \\
\hline Total & & $778.35 \mathrm{~m}^{3} /$ year \\
\hline
\end{tabular}

\section{Water Environmental Carrying Capacity Status}

Status of WECC can be determined by comparing the water availability $\left(S_{A}\right)$ and water demand $\left(D_{A}\right)$.

When $\mathrm{S}_{\mathrm{A}}>\mathrm{D}_{\mathrm{A}}$, the WECC declared in the state of surplus.

When SA < DA, the WECC declared in the state of deficit or exceeded. To analyze the WECC in the study area, the formula written in Equation (5) can also be applied.

$$
W E C C=S_{A} / D_{A}
$$

Where WECC is the water environmental carrying capacity; $S_{A}$ is the water availability; and $D_{A}$ is the water demand. Status analysis:

WECC $<1=$ the WECC is overshoot

WECC 1-3 = the WECC is conditionally-save

WECC $>3=$ the WECC is save

\section{Evaluation of REMRI No.17/2009}

In terms of evaluation of the method used in The REMRI No.17/2009, the writer involved another method i.e. Darcy Law as can be seen in Equation (6) to measure another potential water source (groundwater) as water availability.

$$
Q=K . I . A
$$

Where $\mathrm{Q}$ is the groundwater discharge $\left(\mathrm{m}^{3} / \mathrm{s}\right) ; \mathrm{K}$ is the hydraulic conductivity $(\mathrm{m} / \mathrm{s})$; I is the gradient hydraulic; and A is the area of groundwater flow $\left(\mathrm{m}^{2}\right)$. Furthermore, the total water availability is the addition of the values resulted by Equation (3) and Equation (6).

Regarding to water demand determination, the method explained by was also applied in this research. This method was used to compare the results gained by this method to the previous one given by REMRI No.17/2009. The standard of domestic and non-domestic water demand can be seen in Table 3 where UAYC was categorized in level 2 (the number of inhabitant in UAYC is 695,831 capita). So that, the total water demand is the addition of values in domestic and non-domestic water demand.
TABLE 3. THE STANDARD OF DOMESTIC AND NON DOMESTIC WATER

DEMAND

\begin{tabular}{|c|c|c|c|}
\hline Category & $\begin{array}{c}\text { Number of } \\
\text { inhabitant } \\
\text { (cap) }\end{array}$ & $\begin{array}{c}\text { Domestic } \\
\text { (L/cap/d) }\end{array}$ & $\begin{array}{c}\text { Non Domestic } \\
\text { (\% of } \\
\text { domestic) }\end{array}$ \\
\hline \begin{tabular}{c} 
(Metropolitan) \\
\hline 2 \\
$($ Big city)
\end{tabular} & $\begin{array}{c}500,000- \\
1,000,000\end{array}$ & 135 & 40 \\
\hline $\begin{array}{c}3 \\
\text { (Middle city) }\end{array}$ & $\begin{array}{c}100,000- \\
500,000\end{array}$ & 120 & 40 \\
\hline $\begin{array}{c}20,000- \\
\text { (Small city) }\end{array}$ & 100,000 & 105 & 25 \\
\hline 5 \\
(Rural)
\end{tabular}

All data used in this research were collected by surveying in both field and government institutions. The land use map used as a basis in calculating the water availability was derived from the Rupa Bumi Indonesia Map and satellite imagery which was updated by direct survey in the study area. The data of inhabitant population was derived from the Central Bureau of Statistics (BPS) Yogyakarta continued by the direct in-depth interview to the local government in village.

\section{FINDING AND DISCUSSION}

The research area in UAYC consists of $85.36 \%(7,335 \mathrm{Ha}$ of total 9,677 $\mathrm{Ha}$ ) of built land and the rest is non-built land use. The built-land consists of settlement area, industry, trade, education, hotel, and mall that will increase in the following years along with the population growth. In order to facilitate and support the development in UAYC, many asphalted roads built in this area reaching 1,067 Ha. Consequently, all increasing numbers of built land area will decrease the nonbuilt land use such as rice field, irrigation rice field, park, and pond.

\section{A. Analysis of WECC}

The status of WECC was derived from the comparison between the water availability and water demand in UAYC that can be seen in Table 4 .

TABLE 4. VALUE OF WECC IN UAYC IN 2015

\begin{tabular}{|l|l|l|}
\hline No & \multicolumn{1}{|c|}{ Aspect } & \multicolumn{1}{|c|}{ Value } \\
\hline 1 & Water Availability $\left(\mathrm{m}^{3}\right)$ & $95,385,448$ \\
\hline 2 & Water Demand $\left(\mathrm{m}^{3}\right)$ & $1,113,329,600$ \\
\hline 3 & $\begin{array}{l}\text { Water Environment carrying } \\
\text { Capacity }\end{array}$ & 0.1 \\
\hline
\end{tabular}

The value of WECC is 0.1 which means that the water environmental carrying capacity is overshoot. The number of water demand is significantly higher than the water availability. This very high demand of water is caused by the large number of inhabitant living in the study area reaching 8,100 capita $/ \mathrm{km}^{2}$ of population density. This population density is much higher than that in Sleman and Bantul Regency which are 2,031 and 1,917 capita/ $\mathrm{km}^{2}$ respectively. 
Moreover, the standard of water need applied in this method is quite higher i.e. $1,600 \mathrm{~m}^{3}$ of water/capita/year.

The water availability in UAYC is derived from the calculation by the rational method with the land use as a main parameter. Coefficient runoff is commonly used for determining the amount of water that flows on the surface to the nearest water reservoir (river, pool, etc) (Widodo B.; Lupyanto R.; Sulistiono B.; et al., 2015). The water in this reservoir is one of water source in UAYC, but there are any other sources of water i.e. groundwater and spring that often use as raw water to be then treated by the drinking water company (PDAM) Yogyakarta. It can be concluded that the value of water availability written in Table 4 is still underestimate because the groundwater and spring are not involved yet. In fact, the people living in the study area get water from their own shallow well at home or PDAM which uses groundwater and springs as its water sources.

\section{B. Evaluation of WECC Method mentioned in The REMRI No.17/2009}

The evaluation of WECC Method in REMRI No.17/2009 was conducted by comparing this method with another common method (mix method) mentioned previously. The results of water availability and water demand by mix method can be seen in Table 5 .

TABLE 5. VALUE OF WECC IN UAYC IN 2015

\begin{tabular}{|c|c|c|}
\hline No & Aspect & Value \\
\hline \multicolumn{3}{|c|}{ WATER AVAILABILITY $\left(\mathrm{m}^{3}\right)$} \\
\hline 1 & Runoff (rational method from REMRI 17/2009) & $95,385,448$ \\
\hline 2 & Groundwater & $54,643,210$ \\
\hline \multicolumn{2}{|c|}{ Total Water Availability } & $150,028,658$ \\
\hline \multicolumn{3}{|c|}{ WATER DEMAND $\left(\mathrm{m}^{3}\right)$} \\
\hline 1 & Domestic Water Demand & $34,287,062$ \\
\hline 2 & Non Domestic Water Demand & $13,714,825$ \\
\hline \multicolumn{2}{|c|}{ Total Water Demand } & $48,001,887$ \\
\hline \multicolumn{3}{|c|}{ WECC } \\
\hline $\mathrm{WE}$ & C Value & 3.1 \\
\hline
\end{tabular}

The Indonesian National Standard (SNI 19-6728.1-2002) about determination of water balance mentioned that the water sources are the water reservoir located both on the surface (river, lake, pond, swamp, spring, etc) and under the surface (confined and unconfined groundwater). The mix method used by this study adopted the definition of water sources mentioned in that standard. So that, the determination of water availability by this method was conducted by calculating not only the surface runoff that assumed as a water in pond or river, but also the unconfined groundwater. Thus, the water availability in study area was $150,028,658 \mathrm{~m}^{3} / \mathrm{yr}$. On the other hand, REMRI No. 17/2009 only used the runoff coefficient by rational method as a water availability that can be concluded that it was only the surface water. Hence, the value of the water availability resulted by those two methods are different that can be seen in Table 6 . The value resulted by mix method is much higher that that by REMRI No. 17/2009.

TABLE 6. COMPARISON BETWEEN REMRI No 17/2009 AND MIX METHOD

\begin{tabular}{|c|c|c|}
\hline Aspect & $\begin{array}{c}\text { REMRI No. } \\
\text { 17/2009 }\end{array}$ & Mix Method \\
\hline Water Availability (m3/yr) & $95,385,448$ & $150,028,658$ \\
\hline Water Demand (m3/yr) & $1,113,329,600$ & $48,001,887$ \\
\hline WECC & 0.1 & 3.1 \\
\hline
\end{tabular}

SNI 19-6728.1-2002 mentions that water is used for many purposes such as domestic (house, office, shop, garden, etc), industry, and agriculture. There is a water demand standard for each purpose. However, the mix method applied in this study was not directly adopted from that standard but applied the method mentioned by (Triatmodjo B., 2010). Reference (Triatmodjo B., 2010) explained that the water demand was divided into two classifications such as domestic and nondomestic water demand. The domestic and non-domestic water demand was categorized by the number of population in the study area i.e. category 2 . In this category, the domestic water demand was 135 liter/capita/day and the non-domestic water demand was $40 \%$ of its domestic water demand. From the calculations that the results are shown in Table 5, the total water demand was $48,001,887 \mathrm{~m}^{3} / \mathrm{yr}$. From Table 6 , It can be seen that number of water demand by the method mentioned in REMRI No.17/2009 was significantly higher than that in mix method due to the water demand standard for each person was different; those were 1600 cubic meter/capita/year and 69 cubic meter/capita/year respectively.

By mix method, the WECC value was 3.1 that meant the water carrying capacity in the study area was save or in the state of surplus. This result was likely close to the reality that also confirmed by (Siwi, 2002). Reference (Siwi, 2002) found that the WECC status was conditionally-save with the value of 2.44 in Yogyakarta Urban Area (Yogyakarta City, Sleman, and Bantul) with the total area of 15,535.21 Ha which is larger than the total area of UAYC. This value of water availability found by (Siwi, 2002) was derived from the method of REMRI No.17/2009. On the other hand, the water demand method used in research conducted by (Siwi, 2002) was derived from Public Work Agency of Yogyakarta Province.

From the evaluation, it can be summed up that the REMRI No.17/2009 was suitable or relevant to be used as a long-term approach of the sustainable spatial planning even though there are some parameters need to be discussed in advance. On the other hand, the mix method was also possible to be used as a medium-term approach to make strategy of water resources management and the results gained by this method was closer to the reality than those by the previous one.

\section{CONCLUSIONS AND SugGestions}

The status of water environmental carrying capacity in the study area and the evaluation of the method mentioned in REMRI No. 17/2009 are concluded as follows: 
- The value of WECC was 0.1 which means that the water environmental carrying capacity was overshoot due to the water demand that significantly higher than the water availability, those were $1,113,329,600 \mathrm{~m}^{3} / \mathrm{yr}$ and $95,385,448 \mathrm{~m}^{3} / \mathrm{yr}$ respectively.

- The WECC resulted by REMRI No. 17/2009 was lower than that by Mix Method i.e. 0.1 and 3.1 respectively. The method in REMRI No.17/2009 used only runoff coefficient to measure surface water as its water availability, while the mix method used both runoff coefficient and unconfined groundwater as its water availability. The water demand used in REMRI No.17/2009 and the mixing method has different water demand standard, these are $1600 \mathrm{~m}^{3} /$ capita/year and 69 $\mathrm{m}^{3} /$ capita/year respectively. The REMRI No.17/2009 was relevant to be used as a long-term approach of the sustainable spatial planning even though there are some parameters need to be discussed in advance. On the other hand, the mixing method was also possible to be used as a medium-term approach to making strategy of water resources management.

\section{ACKNOWLEDGMENT}

The writers would like to acknowledge Directorate of research and community services, Directorate general of research strengthening and development, Ministry of research and technology and higher education for the sponsorship through "Penelitian Unggulan Perguruan Tinggi" 2016. We also appreciate the work of LPPM (Institute of Research and Community Services) UPN "Veteran" Yogyakarta that has facilitated the research.

\section{REFERENCES}

[1] Asdak C., and Hilmi S., (2006), "Daya dukung sumber daya air sebagai pertimbangan penataan ruang," Jurnal Teknik Lingkungan P3LT-BPPT, 7(1), 18-25.

[2] Baiquni M., and Chafid Fandeli, (2012), "Studi perkembangan wilayah dan daya dukung lingkungan kepariwisataan di wilayah Yogyakarta Utara," Kawistara, 2 (1), 15-24

[3] Cui X. Q., Sun W.C., Yu J. S., et al, (2013), "Research on dynamic change of water environmental carrying capacity in Henan Province during last ten years, China Population, Resources, and Environment," 23 (11), 359-362.

[4] Fu G.Z., Jia L., Li C., (2013), “A study of water environmental capacity in Wuhan city circle," China Rural Water and Hydropower, (11), 48-51.

[5] Liu C.H., Shen Y.T., Zhou M.Y., et al, (2013), "A quantitative study of urban economic scale constrained by water environmental carrying capacity," Journal of Natural Resources, 28 (11), 1903-1910.

[6] Mustari K., and Mapangaja B., (2005), "Analisis daya dukung lingkungan untuk melaksanakan pembangunan berkelanjutan di Kabupaten Gowa,” Jurnal Ecocelebica, 1 (2), 104-109.
[7] Siwi, (2002), "Analisis daya dukung lahan serta faktor-faktor lingkungan yang mempengaruhinya pada kawasan DAS Tiworo," Kabupaten Muna, Sulawesi Tenggara, CEPI.

[8] Triatmodjo B., (2010), "Hidrologi terapan," Yogyakarta: Gadjah Mada University Press.

[9] Widodo, B., Lupyanto R., Sulistiono B., et al, (2015), “Analysis of environmental carrying capacity for the development of sustainable settlement in Yogyakarta urban area, Procedia Environmental Sciences," 28, 519-527. 